\title{
Gagging the Samoa
}

\section{Observer}

'But with a strong electronic media at its disposal, you wonder why the Government wants the private media under its control, as well. The reason is clear enough. The government does not want the private media to expose acts of corruption.'

\section{By SAVEA SANO MALIFA}

THE PRESS in Samoa, like the country itself, is very small. There are five newspapers - Savali, which is owned by the Government, and the rest are independently owned. The independent ones are Samoa Weekly, all in Samoan; Newsline, bilingual and published twice weekly; the Samoa Observer, which publishes four times a week, and the Sunday Samoan.

Other newspapers published in New Zealand and elsewhere are flown to Apia and sold there.

I am the publisher and English editor of both the Samoa Observer and the Sunday Samoan. Before, I was just editor, but a law passed in 1992 called the Publishers and Newspapers Act, required newspapers to show who their publishers, editors and printers were. From then on, I became publisher as well.

The Government also owns the only TV station in the country, and one of four radio stations. There is one privately-owned FM station, and the rest are owned by churches. Since TV Samoa was set up three years ago, it has not allowed air time to the Opposition.

In Parliament, the late Prime Minister announced the Opposition would not be allowed on TV, because its leader would use it to air his manipulative opinions. He pointed out also that when the present leader of the Opposition was prime minister, he did not allow his party air time on the government-owned Radio 2AP. 


\section{SAVEA SANO MALIFA}

Today, even after Prime Minister Tofilau has passed away, the Opposition is still not allowed on TV Samoa. The present PM, Tuilaepa, has yet to make clear if his administration would remain with the old policy, or devise one of his own.

But with a strong electronic media at its disposal, you wonder why the Government wants the private media under its control, as well. The reason is clear enough. The government does not want the private media to expose acts of corruption.

Some of the the exposés include:

$\square$ The revelation by the press that the Government-owned Polynesian Airlines was dragging the country to near-bankruptcy by accumulating a debt of well over $\mathrm{S} \$ 100$ million.

$\square$ The Controller and Chief Auditor's disclosure of corruption and theft by certain Cabinet ministers and senior government officials.

$\square$ Eight years (by 1994) of no annual accounts tabled in Parliament.

$\square$ A roading contract awarded to a cabinet minister who charged $\$ U S 47,000$ a mile for 26 miles when all the equipment, vehicles, labour and materials used were publicly-owned or funded.

$\square$ The sale of an $\$ 8000$ generator by the same minister to the Public Power Authority for $\$ 89,000$.

$\square$ The take-over by cabinet ministers of publicly-owned cattle farms and land as their own.

$\square$ The passport scandal involving the illegal sale of passports to foreigners in Washington DC, Hong Kong, Tonga, American Samoa and even in Samoa itself

$\square$ The Foreign Investment Bill that was to make legal the sale of citizenship and passports, but was shelved when the scandal was exposed.

Now, come to the Samoa Observer, and what I believe has been a Government campaign to silence it in its quest to suppress public criticism.

\section{Government opposition}

Briefly, the Observer was founded on 28 October 1978, as a weekly. It went on to publish twice a week, then three times, and now four times. It also now publishes one of the country's two Sunday newspapers, the Sunday Samoan.

The campaign began in the early 1980s, when the late Prime Minister sued for $\$ 250,000$ claiming defamation. This was over a story alleging that the PM had received an amount of $\$ 5000$ from a foreign businessman, who had applied 64 PACIFIC JOURNALISM REVIEW 6:1 2000 
for a licence to log the rainforest for export. Later, the company's logging equipment worth millions of dollars were imported duty free, with the explanation that the equipment would be repatriated later. Later still, the equipment was set on fire by angry villagers. The commission of inquiry set up to investigate the fire and the logging operation found that the newspaper report which offended the PM was, in fact, true.

Five years later, the PM's suit was quietly withdrawn.

\section{Other actions}

One morning in 1985, the Minister of Public Works walked into the Observer office and threatened to kill the editor and his family for alleging in a story that he was involved in a theft of government cattle. Two weeks later, the minister sued for defamation claiming $\$ 200,000$ in damages. This suit is still pending.

Members of the newspaper's staff were assaulted in public. One reporter, New Zealand-born, had to return to New Zealand with complicated brain injuries. The person who attacked him was convicted of assault and jailed.

The editor was assaulted by the brothers of the Minister of Public Works. The brothers were charged with assault, they were convicted and sentenced to prison, but the sentences were reduced to fines on appeal.

Then the Minister of Finance sued for defamation, claiming $\$ 250,000$ in damages. This was over a story alleging that money from a bag which came from his office, was later distributed to voters on election day. This information was given as evidence in an election petition trial. The court heard that a car drove down to the minister's office, one occupant went inside it, and soon came out with a bag of money.

Orders were given for the money to be taken to where the elections were held, and distribute it to voters there. This was done, the court was told. Like the PM's suit before it, the Minister of Finance's one was quietly withdrawn, a number of years later.

These three suits cost the newspaper thousands of dollars in legal fees, incurred in the preparation of statements of defence.

In 1982, the Printers and Publishers Act was passed by Parliament. This law requires editors to reveal their sources - and as I have said before - the names of their publishers, editors, and printers, were to be printed prominently in the newspapers.

The main effect of this law soon manifested itself, when correspondents asked not to be named, if their articles were published. They are still doing this 


\section{SAVEA SANO MALIFA}

today. Most of them are either public servants protective of their jobs, business people afraid of offending the government, or expatriates who fear being deported.

\section{Fire}

In April 1994, the Observer's two-story building which housed its editorial office, press and commercial printing, was destroyed by fire. After their investigation, the police and fire service described the fire as "suspicious". This was also the opinion of insurance investigators who said they had discovered several "hot spots" in the debris. To date, the police has yet to produce a report on the fire. But since then, the arsonist has been revealed. I would rather not discuss this matter in detail.

Then came the advertisement ban. The Prime Minister announced that all government departments and corporations were not to advertise any more in the private press, especially the Observer. They were to advertise only in the government-owned media.

\section{Polynesian Airlines}

In January 1997, a light passenger aircraft operated by the government-owned Polynesian Airlines crashed on a mountain killing two passengers and the pilot. A reporter and a photographer from the Observer were the first to get to the crash site by helicopter. They found two survivors, the co-pilot and a young girl.

The subsequent coverage was found offending by airline management who sued for $\$ 1.1$ million. This matter was later settled out of court, and the paper had to pay for its legal fees only.

Late in 1997, the Prime Minister brought a criminal defamatory action against the newspaper, invoking for the first time the first time the Crimes Ordinance Act. It stemmed from a letter to the editor sent by a Samoan living in New Zealand, and was published in the Samoan language. The letter was intended to satirise, but according to the PM, it had damaged his reputation.

I keep thinking of Fear of Flying, whose author, Erica Jong, said:

If we ban whatever offends any group in our diverse society, we will soon have no art, no culture, no humour, no satire.

\section{Criminal libel}

The late PM said that after consulting with his lawyers, he agreed to sue for 66 PACIFIC JOURNALISM REVIEW 6:12000 
criminal libel since civil defamation had failed to stop the Observer from destroying his reputation.

The maximum penalty for criminal libel is six months in jail.

Recently, New Zealand's Justice Moran, who heard constitutional arguments on the matter, has ruled that the criminal libel charge may proceed to court. He was asked to decide whether the letter complained of, was "capable of being criminally libellous."

In his 61-page ruling, Justice Moran, said yes:

I am satisfied that the offence of criminal libel as it exists in Samoa, a creature of the common law with statutory overlay, infringes the applicants' constitutional right to freedom of speech and expression. That infringement, however, is justified as a reasonable restriction on the right, and is not therefore inconsistent with the constitution.

I am further satisfied that the offence of criminal libel as it exists in Samoa does not infringe any of the applicants' other constitutional rights.

The order staying the hearing of the criminal libel charge against both applicants is vacated. The matter may proceed to trail.

The Samoa Observer was represented by New Zealand barrister Lyn Stevens, QC. He wrote to the Attorney-General to exercise her discretion by ordering the matter dropped since the PM has passed away, and failing which, the applicants would appeal.

Just when I was leaving for this conference, I was told that our appeal against Justice Moran's ruling was going ahead on 23 August 1999. I was told also that the late PM's lawyers had pushed for the appeal to go ahead.

Yesterday in this room, reporters' invasion of people's privacy in times of tragedy was a topic seriously debated. In all that time, no mention was made of lawyers' invasion of that same privacy.

Here is a case where a plaintiff who had been made a target of serious allegations in Parliament, and outside it, during his lifetime, had died. And yet his lawyers are still pushing for his claim to be heard in court.

Have they considered that the court hearing could invade his wife's privacy, his children's, and his whole family's? Aren't the lawyers worried that those sad allegations would be made public once again, or are they just concerned about their legal fees which the government would be paying anyway? 


\section{SAVEA SANO MALIFA}

\section{Licence}

At the time when the criminal libel charge was filed, the PM announced in Parliament that the law would be amended to refuse a business licence to the Samoa Observer, and any other publication which stirred up trouble. He repeated this announcement a number of time on public TV.

In 1997 also, the PM sued the Observer for $\$ 400,000$, claiming his reputation was damaged in the coverage of his family's business activities. This involved preparations for the visit by Prince Edward of the United Kingdom. The prince was bringing over funds raised by the Commonwealth Secretariat in London, in a "Pass the Ball" rugby fundraiser.

People in the UK were impressed with Manu Samoa's debut at the 1991 World Cup and wanted to help with rugby development in Samoa. So they raised funds for this purpose. The funds Prince Edward brought were to help build a rugby field in the big island of Savaii, where the PM's family owned an hotel, the Savaiian Hotel.

Although the prince was expected to stay in that hotel, he did not. He returned the same day to the capital of Apia, and stayed at Aggie Grey's Hotel instead.

In a press conference before the prince's arrival, the PM admitted that the government was helping out with the hotel's upgrading, in preparation for the royal visit. Yet several years later when the matter was raised in Parliament, he denied this, declaring that, (and I quote), "Samoa, not a sene [cent] of public funds has been spent on my children's hotel."

Also in Parliament when the Opposition accused him of being a convicted cattle thief, the PM firmly denied this saying, and I quote: "I have never stolen anything in my life because I am the son of a church minister."

Later, it was proven that the PM, along with 27 chiefs of his village, were convicted on 14 June 1966 of cattle theft. They were fined two pounds ten shillings each.

\section{Trial}

At the court hearing of his $\$ 400,000$ claim, the PM's Australian lawyer, Marcus Jacobs, QC, argued strongly that his client would not give evidence. And he succeeded.

The Samoa Observer was represented by another New Zealand barrister, Rodney Harrison, QC.

So in the three-week hearing that followed, the PM was not cross-examined. 68 PACIFIC JOURNALISM REVIEW 6:1 2000 
During the trial, the PM's counsel insisted that the Observer had been engaged in a "vilification campaign against the PM." I denied this in court, and I deny it now.

I want the Samoan judiciary to know that the Observer is not in the business of vilifying people.

Then just as the trial was ending, the Deputy Prime Minister announced that an amount of $\$ 783,000$ in public funds had been allocated to pay for the PM's legal fees. To justify this expense, he said that from then on the public would pay for the legal fees of cabinet ministers, the head of state, members of the council of deputies, and other government leaders, who might allege having been defamed by newspapers.

He explained that this should discourage the press from defaming government leaders. In the government's 1998-99 budget, another $\$ 400,000$ was allocated for this purpose.

In his ruling, however, the presiding New Zealand Supreme Court judge, Sir Gordon Bisson, said it was unusual for a plaintiff not to give evidence to explain how he had been defamed. He also said the defendant was not a witness of truth, and that he was malicious against the PM. I deny those claims then, and I deny them again now.

Today, I'm still wondering what would have happened if the PM had been cross-examined. That is why it is impossible to ignore the feeling that the whole trial was, as one lawyer described it, "clearly one-sided".

\section{A victory}

But there was at least a victory for press freedom arising from this case. The judge ruled that the Observer was

successful in the principal legal argument of the case, namely that the Lange decisions for qualified privilege should apply to Samoa as a proper development of the common law in the interests of freedom of speech and expression in political discussion, without removing the balance needed to prevent defamation.

He then awarded damages of $\$ 50,000$ against the Observer. Soon after the trial, the PM's lawyers submitted their own costs of $\$ 500,000$. I wondered then - and I still do now - how the $\$ 783,000$ (plus the other $\$ 400,000$ ) in public funds that had been pledged for this purpose, had been spent. 


\section{SAVEA SANO MALIFA}

In the end, the judge settled costs at $\$ 75,000$. By then, the paper haD had to pay more than $\$ 300,000$ in legal fees of its own.

But the problems would not go away.

On 16 February 1999, the Australian judge of the Supreme Court, Justice Andrew Bray Cameron Wilson, granted an injunction prohibiting the Samoa Observer from publishing stories on advances made to senior staff of stateowned Polynesian Airlines. The paper had obtained a document saying 21 senior staff had been advanced a total of $\$ 720,000$ up to the end of year 2000 .

The paper did not rush to reveal the contents of the document. Instead, it gave the airline $\mathrm{CEO}$ and top managers the chance to comment on the document. During an interview, they verified that the document was authentic, that it was part of their records. So a story based on this document was to appear in the next day's edition of the Observer.

It quoted the airline deputy CEO, who is a lawyer, Leaupepe Sanirivi, as saying there was "nothing illegal" about the advances. Leaupepe topped the list, with a total of $\$ 254,750$ in advanced allowances and board meeting dues. His advances were made to the "third quarter of year 2000," two of which, for $\$ 21,000$ each, were made on the same day.

Second in the list was finance manager, Sala Petelo, with a total of $\$ 201.621$.

But just as that edition of the Observer was ready for distribution at about five the next morning, the injunction was served at the newspaper's printing plant.

Justice Wilson's injunction ordered the Observer to

refrain from publishing stories relating to salaries, remuneration, allowances and benefits paid to higher ranking employees of the airline, in the Observer issue of 16 February, or any other issue without the prior approval of the plaintiff.

He said he was, (and I quote again), "satisfied that the granting of the interim order sought is necessary to prevent irreparable damage to the airline."

The Observer immediately filed documents seeking removal of the injunction. The hearing that followed was before His Honour, Tiavasu'e Falefatu Sapolu. An application for His Honour to disqualify himself, since he was plaintiff Leaupepe's first cousin, and that his sister, Katalaina Sapolu, was the plaintiff's lawyer, was denied. In the end, His Honour upheld the injunction. 


\section{Dismissal}

Two weeks later, when Leaupepe arrived at the airport from a trip to the United States, he was handed a memo from chief executive, Richard Gates, telling him his services were terminated. During an interview, Leaupepe accepted his dismissal but maintained his loyalty to the airline. Asked what he would do next, he said he might plant some banana crops.

Leaupepe had lived in New Zealand where he ran a private law practice in Auckland. In the early 1980s, he showed up in Samoa and the government appointed him Attorney-General. A few years later, reports that he had been disbarred in New Zealand were publicised locally, and he resigned as AG.

The New Zealand Law Society found that his office had embezzled thousands of dollars of clients' funds, entrusted to its safe-keep.

But from being AG, Leaupepe went to work for Polynesian Airlines as an executive officer and legal adviser.

In 1994, when the airline almost bankrupted the country with more than $\$ 100$ million in debt, the government dismissed several key management officers, but retained Leaupepe.

Today, even as those advances have been publicised world wide, the Samoa Observer is still banned from publishing them.

\section{Conclusion}

And so, r've found that in my 20 years with this newspaper, there has never been a dull moment. The struggle for press freedom has been tiresome, and extremely expensive. In fact, the struggle seems to be never-ending. But along the way, there have been many who offered a helping hand, and moral support.

I think of the World Press Freedom Committee, UNESCO, Commonwealth Journalists Association, Commonwealth Press Union, School of Journalism of Boston University, the Committee to Protect Journalists, E.W. Scripps School of Journalism, Ohio University, the International Freedom of Expression Exchange (IFEX), Pacific Islands News Association, to name just a few of them.

Some of them wrote to our Prime Minister in protest, when he threatened to refuse the Samoa Observer a business licence. They urged him to respect press freedom in our small, isolated country. Their support has indeed been gratifying.

At this point, I want to say that as the brutality against journalists for merely 


\section{SAVEA SANO MALIFA}

doing their jobs is continuing to grow - especially in the Third World - it is no longer enough consoling ourselves that there is hope, as long as these acts of violence are continuing to draw international attention.

Something must be done about threats to press freedom. I believe it is imperative for organisations such as the World Association of Press Councils, to continue to strongly urge its member governments, to respect press freedom above all else.

I say this for the simple reason that this freedom is the soul of a nation, without which, that nation withers and dies. We see this happening around the world, where press freedom is denied. There are wars there, bloodshed, famine, poverty and suffering. Needless to say therefore, press freedom and basic human rights, must be protected at any cost.

All decent-thinking people know that a vigilant press is vital to the survival of freedom, creativity and democracy. Without that freedom, life is miserable.

This freedom is even more needed in small countries in the Pacific, because their governments are young, their economies are often very fragile, and that some of them are run by unprincipled men with one-track visions, who succumb easily to the temptation to get rich quickly at the expense of others.

To achieve their aim, they will do anything to stay in power. This is why they want prying journalists, and press freedom, out of the way. And for that reason alone, the peoples of the South Pacific need press freedom more than ever.

I sincerely believe that government leaders who respect press freedom, do so because they care for their people. Those who don't, should be replaced immediately.

And finally, let me remind all practising journalists with us here today about these words from Sir Winston Churchill, who said:

The only guide for a man is his conscience; the only shield to his memory is the rectitude and sincerity of his actions.

Savea Sano Malifa is publisher and editor of the Samoa Observer and Sunday Samoan in Apia. He gave this address at the World Association of Press Councils' Oceania regional conference in Brisbane on 21-23 June 1999. 